\title{
CRÍTICAS DE MARX, WEBER E LUKÁCS AO CAPITALISMO:
}

\author{
Ideologia, ética e reificação como meios de racionalização e de justificação
}

\section{CRITICISM TO CAPITALISM FROM MARX, WEBER AND LUKÁCS:}

Ideology, ethics and reification as means of rationalization and justification

\author{
Maria Raquel Gomes Maia Pires ${ }^{1}$ \\ (rakas.mr@gmail.com)
}

\begin{abstract}
RESUMO
Este artigo reflete sobre as especificidades, os embates e as articulações das críticas de Marx, Weber e Lukács ao capitalismo, no âmbito da contribuição desses filósofos à teoria crítica da sociedade. Partese da seguinte questão: que articulação é possível fazer entre as críticas de Marx, Weber e Lukács ao pensamento liberal que sustenta o capitalismo? Como argumento central, defende-se que tanto Marx quanto Weber e Lukács - embora com perspectivas conceituais, históricas e filosóficas distintas e por vezes conflitantes - focam suas análises nos meios de racionalização e de justificação do capitalismo na sociedade liberal moderna. Em Marx, discute-se a importância metodológica da transição da circulação para a produção, com ênfase na crítica à ideologia liberal. Em seguida, faz-se uma reconstrução das objeções de Weber à noção de superestrutura marxista, a partir de sua interpretação da ética protestante como meio de justificação ao espírito do capitalismo. Por fim, analisa-se o processo de reificação das relações sociais no capitalismo em Lukács, à luz das críticas feitas por ele à filosofia clássica alemã. Conclui-se que os conceitos de ideologia, ética e reificação dos referidos autores auxiliam na compreensão crítica das entranhas da dominação capitalista.
\end{abstract}

Palavras-chave: capitalismo; Marx; Weber; Lukács; justificação.

\begin{abstract}
This article reflects on the specificities, clashes and articulations of Marx, Weber and Lukács criticisms of capitalism, in the context of the contribution of these philosophers to the critical theory of society. The following question arises: what articulation can be made between the critiques of Marx, Weber and Lukács to the liberal thinking that underpins capitalism? As a central argument, it is supported that both Marx and Weber and Lukacs - although with distinct and sometimes conflicting conceptual, historical, and philosophical perspectives - focus their analyzes on the means of rationalization and justification of capitalism in modern liberal society. In Marx, it is discussed the methodological importance of the transition from circulation to production, with an emphasis on the critique of liberal ideology. Then, Weber's objections to the notion of marxist superstructure is reconstructed, from his interpretation of the protestant ethic as means of justification to the spirit of capitalism. Finally, the process of reification of social relations in capitalism in Lukács is analyzed, in the light of the criticisms he makes to classical German philosophy. It is concluded that the concepts of ideology, ethics and reification of these authors, help in the critical understanding of the bowels of capitalist domination.
\end{abstract}

Key words: capitalism, Marx, Weber, Lukács, justification.

\footnotetext{
${ }^{1}$ Doutora em Política Social pela Universidade de Brasília (UnB).

CV Lattes: http://lattes.cnpq.br/3128153429452472.
} 
Introdução

O presente estudo reflete sobre as especificidades, os embates e as articulações das críticas de Marx, Weber e Lukács ao capitalismo, no âmbito da contribuição desses filósofos para a teoria crítica da sociedade. ${ }^{2}$ Considerando a relevância dos referidos pensadores clássicos para a primeira geração dos teóricos da Escola de Frankfurt, o artigo pretende delinear as possíveis interfaces teóricas e metodológicas das análises empreendidas pelos mesmos acerca dos meios de justificação do capitalismo. Como se sabe, além de Marx, Weber e Lukács influenciaram as produções sobre a dialética do esclarecimento, em Adorno e Horkheimer ${ }^{3}$, assim como as Passagens, de Walter Benjamim, dentre outros representantes dessa corrente (TIEDEMANN, 2009; VASCONCELLOS, 2014).

Nesse contexto, parte-se da seguinte questão: que articulação é possível fazer entre as críticas de Marx, Weber e Lukács ao pensamento que sustenta o capitalismo? O argumento central que norteará a discussão é: tanto Marx quanto Weber e Lukács - embora com perspectivas conceituais, históricas e filosóficas distintas e por vezes conflitantes - focam suas análises nos meios de racionalização e justificação do capitalismo na sociedade moderna.

Para isso, inicialmente discute-se a importância metodológica da transição da circulação para a produção, no Livro I d'O Capital, com ênfase na crítica de Marx à ideologia liberal. Em seguida, faz-se uma reconstrução das objeções de Weber ao materialismo histórico marxista, especialmente à noção de superestrutura, a partir de sua interpretação da ética protestante como meio de justificação ao espírito do capitalismo. Na sequência, analisa-se o processo de reificação das relações sociais no capitalismo em Lukács, à luz das críticas feitas por ele à filosofia clássica alemã. Por fim, faz-se uma síntese articulatória dos conceitos de ideologia, ética e reificação, trabalhados pelos referidos pensadores, como críticas aos processos de racionalização e justificação do capitalismo (MARX, 2013; WEBER, 2004; LUKÁCS, 2003). A despeito das profundas mudanças do capitalismo atual, que exigem releituras desses autores

\footnotetext{
${ }^{2}$ A teoria crítica consiste no desenvolvimento do pensamento marxista pelos filósofos e teóricos da Escola de Frankfurt, que, inicialmente, distinguia-se por seus objetivos metodológicos. Segundo Bottomore e Outhwaite (1996, p. 242): "Uma de suas metas básicas era a incorporação sistemática de todas as disciplinas de pesquisa social científica em uma teoria materialista da sociedade, facilitando assim a mútua fertilização entre a ciência social acadêmica e a teoria marxista".

${ }^{3}$ Sobre o entrelaçamento de Marx, Lukács e Weber na Dialética do esclarecimento, Löwy (2014, p. 119) esclarece: "Seja como for, o diagnóstico pessimista da sociedade moderna esboçado em Dialética do esclarecimento deve muito a Weber - exceto pelo fato de que o ponto de vista dos filósofos de Frankfurt é muito mais radical e inspirado por uma perspectiva marxista-lukacsiana".
} 
a partir da complexidade que o capital assume em tempos de globalização financeira, entendese que a interpretação dos pensadores clássicos é ponto de partida para quaisquer revisitações críticas (HARVEY, 1989; HARDT; NEGRI, 2002).

\section{Marx e a crítica à ideologia da livre troca de equivalentes}

No capítulo IV do Livro I d'O Capital, Marx se pergunta sobre como o dinheiro se transforma em capital ${ }^{4}$, para desvelar o caráter ilusório do capitalismo no processo de produção de mais-valor. Na referida obra, isso é feito em três momentos articulados: (1) a pergunta pela fórmula geral do capital; (2) o desvelamento das contradições dessa fórmula; (3) a análise da compra e venda da força de trabalho para a geração do mais-valor. O presente tópico reinterpretará esses passos de Marx no intuito de identificar a importância metodológica da crítica marxista ao liberalismo.

Para Marx (2013), a circulação de mercadorias é o ponto de partida do capital que, junto com produção, é o pressuposto a partir do qual o valor emerge. Nessa esfera de produção, o dinheiro aparece como produto da circulação. A forma imediata dessa circulação simples pode ser expressa em duas fórmulas: M-D-M (conversão da mercadoria em dinheiro e reconversão em mercadoria) e D-M-D (conversão do dinheiro em mercadoria e reconversão em dinheiro). Detendo-se na forma D-M-D, em especial nos momentos de compra (D-M) e de venda (M-D) que perfazem a troca de mercadorias no capitalismo, Marx identifica que essa forma básica do capital se modifica para sua versão completa. Com isso, a fórmula geral ou completa do capital passa a ser D-M-D', em que D’ corresponde à reconversão do dinheiro inicialmente investido pelo capitalista acrescido de um "mais-valor" ou lucro obtido com a transação.

O que poderia ser uma simples modulação formal da lógica capitalista torna-se para o filósofo um problema central a ser investigado a fim de se desvendar o processo de transformação do dinheiro em capital. Ele analisa de que forma o conteúdo objetivo da

\footnotetext{
${ }^{4} \mathrm{O}$ verbete "capital" no dicionário do pensamento marxista recebe a seguinte definição: "O capital é algo que, em sua generalidade, é bastante específico ao capitalismo; embora o capital seja anterior ao capitalismo, na sociedade capitalista a produção de capital prevalece e domina qualquer outro tipo de produção. O capital não pode ser entendido separadamente das relações capitalistas de produção. Na verdade, o capital não é uma coisa, mas uma relação social que toma a forma de coisa. Sem dúvida, o capital tem a ver com fazer dinheiro, mas os bens que 'fazem' dinheiro encerram uma relação particular entre os que têm dinheiro e os que não têm, de modo que não só o dinheiro é 'feito', como também as relações de propriedade privada que engendram esse processo são, elas próprias, continuamente reproduzidas" (BOTTOMORE, 2001, p. 44).
} 
circulação passa a ser, na verdade, uma "finalidade subjetiva" do capital, como se o mesmo fosse dotado de uma "vontade própria", capaz de se autovalorizar automaticamente. Noutros termos, interessa-lhe saber: por meio de qual "mágica" a fórmula simples da circulação D-MD, calcada no valor de uso nas mãos do capitalista, transforma-se em D-M-D', centrado no valor de troca? Comparativamente, como exemplo, ele afirma que, embora tanto o capitalista quanto o "entesourador" busquem a riqueza, eles se diferenciam na forma como lidam com a circulação. Enquanto o entesourador sai da circulação para acumular riquezas, o capitalista retorna racionalmente a ela para gerar mais-valor (MARX, 2013, p. 295).

Ocorre que, ao inverter a ordem dos processos "antitéticos" da circulação, qual seja, de M-D-M (venda e compra) para D-M-D (compra e venda), altera-se a "natureza" da circulação quase que por mágica, gerando-se o D', ou mais-valor, que precisa ser desvelado. Marx visualiza e desvenda as contradições dessa fórmula geral, principalmente, ao desconstruir as explicações dos empiristas liberais, como Étienne Bonnot de Condillac, que descreve esse acréscimo de valor relacionando-o com as necessidades subjetivas dos compradores e dos vendedores. O equívoco desse argumento, segundo Marx, é que se confunde valor de uso com valor de troca; além disso, espera-se que cada produtor, numa sociedade de produção de mercadorias bem desenvolvida, produza seus próprios meios de subsistência e coloque em circulação apenas o excedente. (MARX, 2013).

Se na forma "pura" a circulação exige uma troca de equivalentes entre mercadoria e dinheiro, as coisas não se passam da mesma maneira na realidade, em sua forma complexa. "Por isso, admitamos uma troca de não equivalentes". Marx insiste em revelar o que estaria por trás do privilégio do "possuidor de mercadorias" em vender mais caro o que ele comprou. Para ele, a classe capitalista não pode se aproveitar de si mesma, uma vez que "da troca de equivalentes não resulta mais-valor, e tampouco da troca de não equivalentes resulta mais-valor. A circulação ou a troca de mercadorias não cria valor nenhum”. Portanto, persiste o problema (MARX, 2013, p. 308).

Mas, se o capital não tem origem na circulação, ele tampouco pode prescindir dela. Curiosamente, e esse é o ponto a ser analisado dialeticamente, "ele tem de ter origem nela e, ao mesmo tempo, não ter origem nela" (MARX, 2013, p. 311). Nas condições materiais para que o dinheiro se transforme em capital, essa mudança precisa acontecer no primeiro ato da circulação, ou seja, na compra de mercadoria para transformar-lhe o valor (D-M). Assim, o capitalista precisaria encontrar uma "mercadoria cujo próprio valor de uso possuísse a característica de ser fonte de valor, cujo próprio consumo fosse, portanto, objetivação de trabalho e, por conseguinte, criação de valor” (MARX, 2013, p. 312). 
Essa mercadoria específica é a capacidade ou a "força de trabalho", definida como "[...] complexo das capacidades físicas e mentais que existem na corporeidade, na personalidade viva de um homem e que ele dispõe em movimento sempre que produz valores de uso de qualquer tipo" (MARX, 2013, p. 312).

Mas onde o capitalista encontra essa força de trabalho disponível para uso e de que forma ele se apropria dela na geração do mais-valor? Exigem-se certas condições ou pressupostos para que o capitalismo prospere. A principal característica que precisa ocorrer é que o próprio possuidor dessa força de trabalho a disponibilize livremente para troca, como mercadoria. Ele precisa dispor dela como "livre proprietário de sua capacidade de trabalho, de sua pessoa". Essa pessoa e uma outra, "possuidora de dinheiro", no entanto, têm de ser “juridicamente livres", visto que se encontram no mercado e estabelecem uma "relação mútua como iguais" possuidores de mercadorias - com a única diferença de que uma é a compradora e a outra é a vendedora (MARX, 2013, p. 313). ${ }^{5}$

Eis, portanto, a "mágica" da transformação de dinheiro em capital parcialmente revelada:

Para transformar dinheiro em capital, o possuidor de dinheiro tem, portanto, de encontrar no mercado de mercadorias o trabalhador livre, e livre em dois sentidos: de ser uma pessoa livre, que dispõe de sua força de trabalho como sua mercadoria, e de, por outro lado, ser alguém que não tem mercadorias para vender, livre e solto, carecendo absolutamente de todas as coisas necessárias à realização de sua força de trabalho. Por que razão esse trabalhador livre se confronta com ele na esfera de circulação é algo que não interessa ao possuidor de dinheiro, para o qual o mercado é uma seção particular de mercado de mercadorias. No momento, essa questão tampouco tem interesse para nós. [...] Uma coisa, no entanto, é clara: a natureza não produz possuidores de dinheiro e mercadorias, de um lado, e simples possuidores da sua própria força de trabalho, de outro. (MARX, 2013, p. 315)

\footnotetext{
${ }^{5}$ Embora fuja aos objetivos deste texto aprofundar as origens do capitalismo, em especial aquelas relacionadas à acumulação primitiva, cabe citar a relevante crítica feminista discutida pela historiadora marxista Silvia Federici (2017). Em sua análise, ela aponta que, enquanto Marx examinou a acumulação primitiva sob o ponto de vista do proletariado assalariado do sexo masculino e do desenvolvimento de mercadorias, faltou-lhe averiguar essas mudanças sob o ponto de vista das mudanças introduzidas na posição social das mulheres, especialmente na relevância de sua atuação na "produção da força de trabalho". Seu argumento é que na divisão capitalista entre a esfera da reprodução, destinada às mulheres, e a da produção, destinada aos homens, esconde-se igualmente a origem dessa força de trabalho "livre", qual seja, o trabalho das mulheres que a produzem. Talvez essa grande desigualdade de gênero seja o ponto que "não interessou" a Marx, como ele afirma na citação acima (p. 315). Sem dúvida, a mágica da reprodução da força de trabalho masculina pública pela produção privada feminina aprofunda ainda mais as injustiças por trás da "ideologia da livre troca de equivalentes", o que revela forte violência contra as mulheres. Noutros termos, para levar "livremente" sua força de trabalho para o mercado, o trabalhador homem possui minimamente algo que o gerou como valor de troca (seja por meio de sua própria gestação, do trabalho doméstico ou de afazeres similares que o sustentam): a apropriação da mulher como mercadoria e de sua força de trabalho, restrita ao lar (FEDERICI, 2017).
} 
Essas condições capitalistas para a criação de mais-valia não estão de modo algum dadas na natureza, mas são processos histórico-dialéticos e, portanto, contraditoriamente forjados por relações sociais desiguais. Uma vez revelado que a exploração da força de trabalho é a "mágica" que o capitalista precisa para gerar seu lucro, advinda da venda mais cara dos produtos oriundos dessa objetivação, surge outra questão: como definir o valor dessa força de trabalho e como ela se valoriza?

O tempo de trabalho produtivo ocupa uma posição importante no cálculo da remuneração do proletariado no capitalismo, em especial na época estudada por Marx. Outro fator relevante é a quantidade de mercadorias necessária para que o próprio trabalhador restabeleça sua subsistência. Nos valores da ideologia burguesa imposta ao proletário, tudo leva o trabalhador a crer que, nessa transação entre os valores consumidos para si e aqueles que ele disponibiliza para a troca, a sua capacidade de trabalho não é nada se não for vendida. Nisso reside a ideologia capitalista que exterioriza e aliena o ser o humano de si mesmo, transformando-o em mercadoria. Alienado de si, o proletário antecipa para o capitalista o valor de uso de sua força de trabalho, entrega-a ao consumo antes de receber o pagamento de seu preço, como um crédito antecipado ao patrão, que assim gera valor antes mesmo de compensar os gastos da produção (MARX, 2013, p. 321).

Na perspectiva dialética de Marx, esse "ocultamento" do processo de trabalho é chamado de "fetichismo da mercadoria", o qual encobre uma contradição inerente ao modo de produção capitalista. Nesse tipo de relação existe uma intrínseca espoliação do ser humano, que passa de sujeito a objeto no processo de produção de "mais-valia". ${ }^{6}$ Nas palavras de Marx:

A mercadoria é misteriosa simplesmente por encobrir as características sociais do próprio trabalho dos homens, apresentando-as como características materiais e propriedades sociais inerentes aos produtos do trabalho; por ocultar, portanto, a relação social entre os trabalhos individuais dos produtores e o trabalho total, ao refleti-la como relação social existente, à margem deles, entre os produtos do seu próprio trabalho. Através dessa dissimulação, os produtos do trabalho se tornam mercadorias, coisas sociais, com propriedades perceptíveis e imperceptíveis aos sentidos. [...] chamo a isso de fetichismo, que está sempre grudado aos produtos

\footnotetext{
${ }^{6}$ Sobre a definição de mais-valia no dicionário marxista, tem-se: "A extração da mais-valia é a forma específica que assume a exploração sob o capitalismo, a differentia specifica do modo de produção capitalista, em que o excedente toma a forma de LUCRO e a exploração resulta do fato de a classe trabalhadora produzir um produto líquido que pode ser vendido por mais do que ela recebe como salário. Lucro e salário são as formas específicas que o trabalho excedente e o trabalho necessário assumem quando empregados pelo capital. Mas o lucro e o salário são, ambos, DINHEIRO e, portanto, uma forma objetificada do trabalho que só se torna possível em função de um conjunto de mediações historicamente específicas onde o conceito de mais-valia é crucial" (BOTTOMORE, 2003, p. 227).
} 
do trabalho, quando são gerados como mercadorias. É inseparável da produção de mercadorias. (MARX, 2013, p. 94)

Noutros termos, a "livre troca de equivalentes" funciona racionalmente como uma justificação ideológica desse "fetichismo", na medida em que torna formalmente igual o que é socialmente desigual na sociedade capitalista. No caso do trabalhador, para que essa ideologia seja eficaz, ele precisa se considerar livre para trocar mercadorias (sua força, sua essência, ele próprio) com o possuidor de dinheiro, sendo ambos tratados formalmente como equivalentes no reino encantado do mercado.

Nessa perspectiva marxista, a circulação é vista na sociedade capitalista como um "Éden dos direitos inatos do homem", um reino da liberdade, da igualdade e de Bentham. "Liberdade" porque os compradores e vendedores seriam movidos por seu "livre-arbítrio"; "igualdade" por se relacionarem como "possuidores de mercadorias" que trocam equivalentes; e "Bentham" "pois cada um olha somente para si mesmo". É justamente essa individualidade que sustenta uma "harmonia preestabelecida das coisas", "uma providência todo-astuciosa" mantedora do “interesse geral” (MARX, 2013, p. 323).

A maquiagem dessa farsa, que na realidade social esconde profundas desigualdades, é desfeita na ironia do próprio Marx, na frase que encerra o capítulo:

O antigo possuidor de dinheiro se apresenta agora como capitalista, e o possuidor da força de trabalho, como seu trabalhador. O primeiro, com um ar de importância, confiante e ávido por negócios; o segundo, tímido e hesitante, como alguém que trouxe sua própria pele ao mercado e, agora, não tem mais nada a esperar além da despela (MARX, 2013, p. 323).

2. Weber: ética protestante na justificação do capitalismo e a crítica ao materialismo histórico

No caso da última cena relatada por Marx no tópico anterior, qual seja, a do trabalhador que segue seu destino de "despela" no mercado de troca capitalista, é possível supor que Weber se perguntaria pelo que conformaria o comportamento disciplinado, resignado e ascético do referido personagem. Que espécie de "ethos" predisponente ao "espírito capitalista", favorecedor do enriquecimento e da exploração do ser humano, explicaria tamanha 
missão "vocacional”? Que elementos culturais seriam capazes de mobilizar voluntariamente uma pessoa para um "abate" mais do que previsto?

Em verdade, as inquietações e as observações weberianas começam também pelo ponto de vista dos capitalistas, devido à forte presença do protestantismo entre eles, especialmente nas regiões da América do Norte, Inglaterra e países nórdicos. Notadamente, em boa parte dos locais em que a Reforma Protestante prosperou observou-se um desenvolvimento econômico sem precedentes, aspecto que fez com que Weber se colocasse uma questão inicialmente histórica: "qual a razão dessa predisposição particularmente forte das regiões economicamente mais desenvolvidas para uma revolução na Igreja?” (WEBER, 2004, p. 30).

N'A Ética protestante e o espírito do capitalismo, discute-se justamente essa simbiose entre o credo religioso conformador de um "ethos" e a lógica de racionalização capitalista. Nessa obra, Weber delimita o seu objeto de investigação em três partes, a saber: (1) confissão religiosa e estratificação social; (2) espírito do capitalismo; e (3) conceito de vocação em Lutero. Uma vez colocado o que chamou de "questão histórica", enunciada acima, o pensador adentra nas especificidades da Reforma, que em sua análise, ao invés de ter diminuído a dominação eclesiástica, aumentou-a significativamente. Ele afirma que o centro das críticas dos reformadores à Igreja Católica não era exatamente o excesso de controle sobre o indivíduo, mas justamente o seu oposto, ou seja, a "indulgência" para com os pecadores, a despeito da histórica perseguição aos "hereges".

Disso decorre que os protestantes (certas correntes internas), sejam eles capitalistas ou trabalhadores, mostraram uma forte inclinação para o "racionalismo econômico", que "não pode ser igualmente observada entre os católicos, nem numa nem noutra situação”. Seria o caso, então, de averiguar os elementos dessas “confissões" religiosas que influenciaram tal afinidade entre a fé religiosa e a inclinação para os negócios - ao lado de seu disciplinamento resignado para o trabalho, como no caso dos proletários. (WEBER, 2004, p. 34).

A partir desse intrínseco parentesco entre, por um lado, o "estranhamento do mundo, a ascese e a devoção eclesial" e, por outro, a "participação na vida de aquisição capitalista", Weber coloca a seguinte questão: “Terá havido porventura uma conexão entre sua superioridade no campo dos negócios - e, num outro contexto, seu pendor para instituições políticas livres -

\footnotetext{
${ }^{7}$ Mais uma vez, recorro à Federici (2017) para acrescentar que, em continuidade ou mesmo em extensão à perseguição dos hereges, o movimento de caça às bruxas na Europa, nos séculos XVI e XVII, constituiu um grande contributo à acumulação primitiva do capitalismo. Vale lembrar que as bruxas caçadas eram principalmente mulheres com atividades que desafiavam o disciplinamento dos corpos, tão necessário à produção da mais-valia, tais como: a das curandeiras, das feiticeiras, das parteiras, das camponesas rebeldes à desapropriação das terras e ao desencantamento, dentre muitos outros "corpos rebeldes" (Calibãs), em boa parte femininos.
} 
e esse recorde de devoção que Montesquieu reconheceu nelas?" A referência a Montesquieu se dá em vista de sua afirmação de que os ingleses foram o povo que melhor prevaleceu na religião, no comércio e na liberdade (WEBER, 2004, p. 39).

Uma vez problematizada a crítica weberiana ao capitalismo, ou as explicações para seu respectivo avanço em determinadas regiões protestantes da Europa ocidental e da América, passa-se à discussão do "espírito do capitalismo". Entendido como uma "individualidade histórica" dotada de significação cultural, o "espírito do capitalismo" é delineado de maneira aproximativa e regular, como parte do método de investigação weberiano, no qual a busca por uma compreensão mais ampla, histórica e processual de conceitos é necessária, antes de configurá-los como "tipos ideais" - visto como um conceito-limite ideal, forjado com o propósito de esclarecer certo conteúdo empírico da realidade. ${ }^{8}$

$\mathrm{O}$ "ethos" expresso numa forma particular de fazer negócio, como exemplificado na ideia de "ganhar dinheiro, e sempre mais dinheiro", de Benjamin Franklin, é o que Weber se interessa em discutir, no âmbito do "espírito" do capitalismo - ou seja, o ser humano em função do ganho como finalidade de vida, e não o contrário. Essa inversão, longe de ser "natural", perfaz o "Leitmotiv do capitalismo", que, na ordem econômica moderna, é o resultado de cercas visões e habilidades profissionais forjadas pela cultura e pela moral. Nesse contexto, a "profissão como dever" aparece como um valor e uma "ética" necessários ao desenvolvimento de riquezas (WEBER, 2004, p. 47).

O domínio do capitalismo sobre a vida econômica das pessoas precisaria, portanto, forjar para si mesmo esses "sujeitos econômicos", sejam empresários ou operários. No entanto, para que essas "condutas de vida" pudessem emergir, primeiramente elas teriam de nortear um "modo de ver" não apenas de indivíduos, mas também de determinados grupos de pessoas. Nesse ponto reside a principal crítica de Weber ao materialismo histórico, pois para ele tais

\footnotetext{
${ }^{8}$ Sobre tipos ideais, é o próprio Weber quem esclarece: "Qual a significação desses conceitos de tipo ideal para uma ciência empírica, tal como nós queremos praticá-la? Queremos sublinhar desde logo a necessidade de que os quadros de pensamento que aqui abordamos, 'ideias' em sentido puramente lógico, sejam rigorosamente separados da noção do dever ser, do 'exemplar'. Trata-se da construção de relações que parecem suficientemente motivadas para a nossa imaginação e, consequentemente, 'objetivamente possíveis', e que parecem adequadas ao nosso saber nomológico. [...] se quisermos tentar uma definição genérica do conteúdo do conceito, restar-nos-á apenas a forma do tipo ideal, no sentido anteriormente estabelecido. Trata-se de um quadro de pensamento, não da realidade histórica, e muito menos da realidade 'autêntica'; não serve de esquema em que se possa incluir a realidade exemplar. Tem, antes, o significado de um conceito-limite, puramente ideal, em relação ao qual se mede a realidade a fim de esclarecer o conteúdo empírico de alguns dos seus elementos importantes, e com o qual esta é comparada. Tais conceitos são configurações nas quais construímos relações, por meio da utilização da categoria de possibilidade objetiva, que nossa imaginação, formada e orientada segundo a realidade, julga adequadas" (WEBER, 2001, p. 138-140).
} 
ideias não são geradas por "superestruturas de situações econômicas", forma de ver e se portar em sociedade, com influências culturais específicas. Em suas palavras:

Portanto, é essa a emergência de um modo de ver que se trata propriamente de explicar. Só alhures teremos ocasião de tratar no pormenor daquela concepção do materialismo histórico ingênuo segundo o qual "ideias" como essa são geradas como "reflexo" ou "superestrutura" de situações econômicas. Por ora, é suficiente para o nosso propósito indicar: que na terra natal de Benjamin Franklin (o Massachusetts) o "espírito do capitalismo" (no sentido por nós adotado) existiu incontestavelmente antes do "desenvolvimento do capitalismo". (WEBER, 2004, p. 48)

Para Weber, o adversário com que o "espírito do capitalismo", enquanto determinado "estilo de vida regido por normas e folheado a ética", sempre teve de lutar foi e continua sendo o "tradicionalismo". No âmbito de seu referido método de aproximação conceitual, o primeiro sentido dado a esse termo diz respeito àquela forma "natural" do ser humano de apenas continuar vivendo como sempre viveu, e não movido por um interesse por "ganhar dinheiro e sempre mais dinheiro". Para que esse objetivo do lucro se tornasse um fim, ocorreram mudanças nas formas de se comportar das pessoas.

Novamente, cabe a suspeita weberiana de que a capacidade de adaptação ao capitalismo fora favorecida por fatores religiosos, como modos de justificação para determinadas condutas de vida. Nesse sentido, o disciplinamento do trabalho visto como uma "vocação" ou um "dever como um fim em si mesmo" aparece como solo fértil para superar o "tradicionalismo" de querer se viver como sempre se viveu. Para Weber, a tenacidade, a resignação, a aceitação de um destino divino, a firmeza e o disciplinamento ascético propagado por algumas religiões protestantes, inscritos na ideia de "vocação" como uma missão a ser cumprida, coadunaram-se muito bem ao "espírito do capitalismo", que requer o autocontrole, a disciplina, a determinação, a perseverança e a disposição para o ganho como comportamentos desejáveis. (WEBER, 2004, p. 56-57).

Nos relatos de Weber, a educação religiosa pietista de certas moças da época contribuiu, por exemplo, para que elas fossem dotadas de forte capacidade de concentração, associada à

\footnotetext{
${ }^{9} \mathrm{O}$ conceito de base e superestrutura, em Marx, é explicado no dicionário do pensamento marxista da seguinte forma: "A metáfora do edifício - base (infra-estrutura) e superestrutura - é usada por Marx e Engels para apresentar a ideia de que a estrutura econômica da sociedade (a base ou infraestrutura) condiciona a existência e as formas do ESTADO e da consciência social (a superestrutura). [...] Mas o caráter da relação entre base ou infraestrutura e superestrutura é mais complexo do que essas formulações poderiam levar a crer. Marx tem consciência de que a determinação da infraestrutura pode ser mal entendida como uma forma de reducionismo econômico. É por isso que ele caracteriza também essa relação como histórica, desigual e compatível com a eficácia da superestrutura" (BOTTOMORE, 2003, p. 27).
} 
atitude de sentirem-se no "dever de trabalhar". Além disso, o rigoroso espírito de poupança, o severo domínio de si e a sobriedade puritana puderam aumentar consideravelmente a produtividade do trabalho. Pelo lado dos empresários alemães, seu "tipo ideal" inclui semelhantes comportamentos ascéticos, tais como: uma esquiva à ostentação e à despesa inútil; um gozo consciente de seu poder; um incômodo com as deferências externas que recebe; uma forte determinação em vencer obstáculos dos comportamentos "tradicionalistas" que inibem o avanço dos negócios. Isto é, nesse tipo de empresário, vê-se que de sua riqueza ele "nada tem para si mesmo, a não ser a irracional sensação de cumprimento do dever profissional” (WEBER, 2004, p. 63).

Retorna aqui o alvo da crítica weberiana à ideia de superestrutura marxista como reflexo das condições materiais de existência. Em sua análise, ao contrário dos condicionantes econômicos que se refletem numa dada consciência de classe, fora necessário criar um conjunto de ideias que favorecessem determinados estilos de comportamento moral mais afinados com a racionalidade capitalista. Ele exemplifica historicamente o fato do crescimento econômico moralmente condenável de Florença, nos séculos XIV e XV, em comparação com o provincianismo pequeno-burguês da Pensilvânia do século XVIII, em que, diante da crise econômica, o comportamento de escambo da população fora não apenas louvado, como estimulado. Diante disso, provoca:

Querer falar aqui de um "reflexo" das condições "materiais" na "superestrutura ideal" seria rematado absurdo. De que círculo de ideias originou-se pois a inclusão de uma atividade voltada puramente para o ganho na categoria de "vocação", à qual o indivíduo se sentia vinculado pelo dever? Pois foi essa a ideia que conferiu à conduta de vida do empresário de "novo estilo" base e consistências éticas. (WEBER, 2004, p. 66)

Ao constatar a relevância da "vocação" - isto é, aquilo que o indivíduo aceita como desígnio divino incondicional - para o desenvolvimento do capitalismo, Weber questiona igualmente o sentido do "racionalismo prático (entendido como todo tipo de conduta de vida que reporta conscientemente o mundo dos interesses intramundanos)" na determinação de uma produtividade centrada em valores de troca próprios ao capitalismo. Diferentemente disso, o caráter "irracional" da fé religiosa lhe despertou a necessidade de averiguar mais de perto as “afinidades eletivas" entre religião, ética profissional e capitalismo (WEBER, 2004, p. 68).

Assim, embora Weber realize tanto quanto Marx uma forte crítica à dominação do capitalismo sobre a vida das pessoas, sua argumentação segue em direção oposta à “ideologia da justa troca de equivalentes”. Na análise weberiana, 
trata-se muito mais de desvelar as influências culturais religiosas como formas de justificação individuais que - embora fujam ao sentido estrito do "racional", centrado num "eu individual" que julga seus interesses - são capazes de sustentar muito mais o "espírito" capitalista.

De volta à metáfora ilustrada por Marx acerca de um suposto encontro no reino do mercado entre o capitalista todo poderoso e o trabalhador hesitante que segue de cabeça baixa para sua "despela", poder-se-ia dizer, com Weber, que fora necessário forjar uma ética própria para que essa situação se tornasse possível. Ou seja, o espírito que anima as relações produtivas no capitalismo seria movido muito mais por uma "vocação" profissional, tal qual um destino a ser cumprido resignada e asceticamente, do que pelos reflexos ideológicos da "superestrutura" marxista.

\section{Lukács: reificação da consciência e crítica à filosofia clássica Alemã}

Pode-se visualizar no conceito de reificação da consciência crítica, em Lukács, uma possível articulação entre o materialismo histórico marxista e os fenômenos culturais analisados por Weber, se esse processo de "coisificação" das relações sociais for percebido como um fenômeno de racionalização e de justificação da sociedade capitalista. Essa suposição aparece discretamente desde o objetivo do capítulo "Reificação e consciência de classe", em História e consciência de classe, assim como no restante da discussão lukacsiana. A intenção do filósofo é, a partir das análises marxistas do fetichismo da mercadoria, chamar a atenção para os problemas da objetividade e da subjetividade que dele decorrem (LUKÁCS, 2003, p. 194).

Para Lukács, a ação desagregadora da troca de mercadorias, para surtir o efeito reificante, deve se voltar não apenas para o interior da estrutura social, mas penetrar igualmente no conjunto das manifestações vitais da sociedade, remodelando-as à sua própria imagem. Subjetivamente, quando a atividade do ser humano se objetiva em relação a ele, tornando-se uma mercadoria que lhe é estranha, essa "coisa" produzida passa a ser determinada por leis "naturais" que regem os comportamentos individuais e coletivos de uma sociedade baseada em valores de troca. Nesses termos, a universalidade da mercadoria condiciona o trabalho humano tanto objetiva quanto subjetivamente (LUKÁCS, 2003, p. 200). Ou seja:

Trata-se somente de constatar que o trabalho abstrato, igual, comparável, mensurável com uma precisão crescente em relação ao 
tempo de trabalho socialmente necessário, o trabalho da divisão capitalista de trabalho, que existe ao mesmo tempo como produto e condição da produção capitalista, surge apenas no curso do desenvolvimento desta e, portanto, somente no curso dessa evolução ele se torna uma categoria social que influencia de maneira decisiva a forma de objetivação tanto dos objetos como dos sujeitos da sociedade emergente, de sua relação com a natureza, das relações dos homens entre si que nela são possíveis. (LUKÁCS, 2003, p. 201)

Lukács cita as análises "psicológicas" do sistema Taylor para acrescentar que a mecanização racional do processo de trabalho penetra na "alma" do trabalhador. Com isso, suas qualidades psicológicas são separadas de sua personalidade e objetivadas em relação a ela, sendo incorporadas em sistemas racionais baseados no cálculo. É justamente esse princípio da "possibilidade do cálculo" que interessa ao filósofo, e por duas razões: (1) para poder calcular o processo de trabalho, é preciso romper com a "unidade orgânica irracional do produto", tornando-o uma reunião objetiva de sistemas parciais racionalizados. Isso significa que a "racionalização é impensável sem a especialização"; e (2) a fragmentação do objeto implica necessariamente a fragmentação do sujeito, incorporado como parte mecanizada do mesmo como sua objetivação (LUKÁCS, 2003, p. 202-203).

A partir da separação entre produtor e meios de produção, da dissolução das unidades originais de produção e das condições sociais e econômicas do nascimento do capitalismo, advém o fenômeno da "reificação": uma substituição das relações originais humanas por formas de objetivação sociais. Para a "consciência reificada", as formas do capital se transformam nos representantes de sua vida social, porque neles se "esfumam" as relações dos seres humanos entre si e com os objetos reais, destinados à satisfação de suas necessidades (LUKÁCS, 2003, p. 207, 211).

A partir das considerações de Weber sobre a prioridade do cálculo para a empresa capitalista moderna, Lukács constata que a divisão do trabalho penetrou igualmente na "ética", tal qual o taylorismo penetrou no "psíquico", aprofundando a reificação da consciência. Dessa forma, o sujeito da troca se torna tão abstrato, formal e reificado como seu objeto:

O gênero específico de "probidade" e objetividade burocráticas, a submissão necessária e total do burocrata individual a um sistema de relações entre coisas, a ideia de que são precisamente sua "honra" e seu "senso de responsabilidade" que exigem dele semelhante submissão, tudo isso mostra que a divisão do trabalho penetrou na "ética" - tal como, no taylorismo, penetrou no psiquismo. Isso não é, todavia, um abrandamento, mas, ao contrário, um reforço da estrutura reificada da consciência como categoria fundamental para toda a sociedade. (LUKÁCS, 2003, p. 221) 
A principal característica da reificação da consciência é seu imediatismo, ao lado da inibição dos processos de mediação do pensamento, que segue atrelada a processos de representação. Sob o ponto de vista filosófico, caberia perguntar de onde surge a sustentação dessa reificação. Para o filósofo marxista, em sua crítica, a filosofia moderna nasceu dessa estrutura reificada de consciência e contém problemas semelhantes aos das ciências particulares, fundadas na permanente cisão entre o sujeito e o objeto do conhecimento. Para ele, o aprofundamento dessa fratura entre o que podemos conhecer racionalmente e o que não podemos, assumido imediatamente pelas ciências empíricas, igualmente é reproduzido pelo sistema kantiano, alvo principal de suas objeções.

Nas “antinomias do pensamento burguês", Lukács inicia por argumentar que a filosofia moderna não aceita mais o mundo como algo independente do sujeito cognoscente (criado por Deus, por exemplo), mas como produzido por ele, portador do cogito cartesiano. Além disso, o racionalismo burguês reivindica um método universal para o conhecimento da totalidade do ser. Com o sistema kantiano, achou-se possível que a razão crítica e, especificamente, a "coisa em si" preenchessem funções distintas da metafísica tradicional ou das ciências empíricas. No entanto, para o filósofo, o que todas têm em comum é a criação de barreiras intransponíveis entre o que podemos conhecer racionalmente e o que é vedado à cognição humana.

Para Lukács, a semelhança entre as ciências e a filosofia clássica alemã moderna se expressa em dois conjuntos de problemas: (1) a dualidade entre a matéria e o conteúdo das formas; (2) a inacessibilidade à razão dos objetos "últimos" do conhecimento, a totalidade. Para ele, a "grandeza, o paradoxo e a tragédia da filosofia clássica alemã" é que ela não conseguiu fazer desaparecer todo "dado" como inexistente por detrás da racionalidade, reforçando a dicotomia entre a forma e o conteúdo dos conceitos. Com isso, a filosofia clássica alemã teria conseguido superar suas antecessoras e derrubar os "fundamentos do método dialético" (LUKÁCS, 2003, p. 247, 252, 254).

Diante disso, a análise lukacsiana se propõe a mostrar como essas "antinomias" integram o "pensamento burguês" e reforçam os processos de reificação das relações sociais capitalistas. Isso porque o sistema kantiano, mesmo na perspectiva ética da razão prática, reproduz o mesmo problema da irracionalidade da "coisa em si", com o agravante de que o terreno da liberdade passa igualmente a ser incognoscível. Ora, essa impossibilidade de conectar forma e conteúdo concretamente, e não apenas como cálculo formal, torna insolúvel o "dilema da liberdade e da necessidade, do voluntarismo e do fatalismo" (LUKÁCS, 2003, p. 281). 
Longe de ser uma problemática erudita, o pensador aponta as principais consequências práticas dessas muitas manifestações da cisão entre universal e particular, quais sejam: (1) com o desenvolvimento da sociedade burguesa, todos os problemas deixam de transcender ao homem e se manifestam como produto de sua atividade; (2) esse "homem" é o "burguês, egoísta, individual e artificialmente isolado pelo capitalismo", tal qual a sua consciência; e (3) é justamente dessa forma que se suprime a força da ação social, ou o esvaziamento da política. Com isso, cresce o sentimento de que as formas reificadas de consciência aprofundam a fragmentação do ser humano e que, quanto mais a cultura e a civilização capitalista se apossam dele, mais ele se afasta de sua humanidade (LUKÁCS, 2003, p. 283, 285).

Mas o que seria essa "humanidade" perdida? Nesse ponto, Lukács retoma as posições de pensadores alemães, como Schiller, influenciados pelo ideal de um certo "estado de natureza" de Rousseau, para igualmente apontar limitações. A natureza aqui é vista como sinônimo de um "ser humano autêntico", essencial, verdadeiro, liberado das falsas formas de socialização da cultura, visto como uma "totalidade acabada", que superou a cisão entre "razão e sensibilidade", levando a crer que existe um reino onde a necessidade e a liberdade coincidem. Essas concepções estão inscritas igualmente na aposta do poder da arte como uma força capaz de ressuscitar esse ideal de liberdade.

No entanto, Lukács argumenta que a fruição calcada na filosofia estética do romantismo clássico alemão, ao contrário de libertar a reificação da consciência humana, encrustada nas antinomias do pensamento burguês, nada mais faz do que recriar formas sutis de fragmentação desse sujeito, uma vez que o reino da arte continua tão irracional e incognoscível quanto o sistema da razão kantiano; muito embora, a esse respeito, ele pondere que Kant anteviu na potência do "juízo reflexionante"10 uma possível mediação entre os contrários inconciliáveis (a saber: a relação entre forma e conteúdo, singular e universal, conhecimento e coisa em si etc.) que seu próprio sistema criara. ${ }^{11}$

\footnotetext{
${ }^{10}$ No dicionário Kant, eis a definição de juízo reflexionante: "Na primeira e na segunda introdução à CJ, Kant distingue entre formas determinantes e reflexivas de juízo. O juízo, em geral, é descrito como 'a faculdade de pensar o particular como contido no universal', e se o universal já é dado 'então o juízo que subsume o particular sob ele é determinante' (CJ §IV). Se, por outro lado, 'só o particular é dado e o universal tem de ser encontrado sobre ele, então o juízo é simplesmente reflexivo' (ibid.). O juízo reflexivo 'é compelido a ascender do particular na natureza para o universal' e, diz Kant, 'necessita de um princípio'. Esse princípio não pode ser universal, uma vez que isso tornaria o juízo determinante, mas está localizado por Kant no juízo que se propõe a si mesmo o princípio reflexivo da 'finalidade da natureza"' (CAYGILL 2000, p. 209).

11 Acerca da importância teórica, sistemática e ideológica que o princípio da arte assume no romantismo clássico do século XVIII, Lukács (2003, p. 288-290) assim se refere à contribuição de Kant: "Esse princípio é a criação de uma totalidade concreta em virtude de uma concepção da forma orientada justamente para o conteúdo concreto do seu substrato material, capaz, por conseguinte, de dissolver a relação 'contingente' dos elementos com o todo, de superar a contingência e a necessidade
} 
Se essa tentativa de solução é vista como uma possibilidade em Kant, ela é assumida como princípio fundamental entre seus sucessores, como Fichte e Schiller. Porém, a íntima relação da arte com essa perfectibilidade abstrata de uma certa natureza perdida traçou um destino de "solução para todos os problemas", precipitando seu próprio fracasso. Noutras palavras, seria como substituir a universalidade de Deus ou da coisa em si pelo ideal transcendente da arte. Para Lukács, nessas saídas inspiradoras da arte, "em última análise, portanto, trata-se de produzir o sujeito produtor" (LUKÁCS, 2003, p. 293).

No que concerne a Hegel e sua dialética para unificar um "nós" entre o sujeito e o objeto, há muito perdido, Lukács admite sua enorme contribuição, mas igualmente afirma que ele cedeu à tentação de um "espírito absoluto" inatingível, intangível e incognoscível. Diz ele:

Eis aqui o ponto em que a filosofia de Hegel é inexoravelmente levada à mitologia. Pois, na impossibilidade de encontrar e demonstrar o sujeito-objeto idêntico na própria história, sua filosofia é obrigada a transcender e erigir fora dela esse reino da razão que ascendeu a si próprio. A partir dele, a história pode então ser compreendida como uma etapa, e o caminho que percorre como uma "astúcia da razão". A história não está em condições de constituir um corpo vivo da totalidade do sistema: torna-se uma parte, um aspecto do sistema como um todo, que culmina no "espírito absoluto", na arte, na religião e na filosofia. (LUKÁCS, 2003, p. 304-305)

$\mathrm{Na}$ análise lukacsiana, a filosofia clássica alemã levou ao extremo as antinomias de seu fundamento e deu-lhe a mais forte expressão intelectual. A despeito de querer superar no pensamento a sociedade burguesa, ela não conseguiu mais do que sua reprodução. Porém, um certo modo dessa dedução, diz ele, o método dialético, pode apontar para além desse pensamento liberal burguês (LUKÁCS, 2003, p. 308).

Num regresso à metáfora do capitalista predador e do trabalhador docilmente disciplinado imaginada por Marx, a análise de Lukács confere novos elementos explicativos. Em sua visão, ele foi capaz de entrelaçar, numa mesma consciência reificada, tanto a objetivação das relações produtivas humanas quanto a subjetivação da primazia do cálculo disciplinado do espírito capitalista, ambas necessárias à valorização dialética do capital. ${ }^{12}$

\footnotetext{
como contrários simplesmente aparentes. É sabido que Kant, já na Crítica do Juízo, atribuiu a esse princípio o papel de mediação entre os contrários de outra forma inconciliáveis, portanto, a função de acabamento do sistema. Porém, essa tentativa de solução não podia ater-se à explicação e interpretação do fenômeno da arte [...]. Se, para o próprio Kant, isso mostra apenas o ponto a partir do qual o sistema poderia ser fechado e acabado, esse princípio e a exigência de um entendimento intuitivo dele resultante e de sua intuição intelectual tornam-se em seus sucessores a pedra fundamental da sistemática filosófica".

12 Sobre a síntese que Lukács, com o conceito de reificação, teria realizado do fetichismo da mercadoria em Marx e da racionalização em Weber, Löwy (2014, p. 113) comenta: "Podemos
} 
Noutras palavras, é a consciência reificada e quantificada do trabalhador - forjada dialeticamente com as condições materiais de produção - que o torna apartado de si e o faz aderir livremente aos termos da "despela" capitalista.

\section{Conclusão}

Marx atribui à "ideologia da livre troca de equivalentes" uma forma de sustentar o fetichismo da mercadoria, como elementos dialéticos da base e superestrutura da dominação capitalista. Em contraponto, Weber argumenta que o desenvolvimento do capitalismo foi favorecido, em muitos aspectos, por um "ethos" próprio à ascese protestante, que forjou sujeitos econômicos resignados ao mundo dos negócios e do dinheiro, fruto de uma "vocação profissional" mundana de inspiração divina. Numa possível articulação entre o materialismo histórico e a influência da cultura, o conceito de reificação, em Lukács, desvenda as origens do "feitiço" da mercadoria em modalidades de pensamento cindidas entre forma e conteúdo, as quais objetificam as relações sociais. Em todos os três pensadores, de distintas maneiras, vê-se que os conceitos de ideologia, ética e reificação auxiliam na compreensão das entranhas justificadoras da dominação capitalista.

\footnotetext{
considerar que o capítulo central de História e consciência de classe, baseado na análise de reificação (Verdinglichung), é uma síntese poderosa e original da teoria do fetichismo da mercadoria de Marx e da teoria da racionalização em Weber. Fundindo a categoria weberiana da racionalidade formal caracterizada pela abstração, pela 'coisificação' (Versachlichung) e pela quantificação - com as categorias marxianas de trabalho abstrato e valor de troca, Lukács reformulou a temática do sociólogo alemão na linguagem teórica marxista. Por outro lado, estendendo a análise marxiana da forma de mercadoria a outros domínios da sociedade e da cultura, ele se inspira diretamente nas análises weberianas da vida moderna, impregnada pelo espírito capitalista de cálculo racional (Rechenhaftigkeit). Segundo Lukács, a transformação de todos os objetos em mercadorias e sua quantificação enquanto valores de troca fetichistas resultam na perspectiva de uma progressão infinita que leva a uma racionalização capitalista melhorada da existência social em sua totalidade".
} 
Referências

BOTTOMORE, Tom. Dicionário do pensamento marxista. Tradução de Waltensir Dutra. Rio de Janeiro: Jorge Zahar Editora, 1983

CAYGILL, Howard. Dicionário Kant. Tradução de Álvaro Cabral. Revisão técnica de Valério Rohden. Rio de Janeiro: Jorge Zahar, 2000.

FEDERICI, Sílvia. Calibã e a bruxa: mulheres, corpo e acumulação primitiva. Tradução de Coletivo Sycorax. São Paulo: Editora Elefante, 2017.

HARVEY, David. A condição pós-moderna - uma pesquisa sobre as origens da mudança cultural. Tradução de Adail Ubirajara Sobral e Maria Stela Gonçalves. São Paulo: Loyola, 2003.

HARDT, Michael; NEGRI, Antonio. Império. Tradução de Birilo Vargas. 1 ed. Rio de. Janeiro: Record, 2002.

LUKÁCS, György. História e consciência de classe - estudos sobre a dialética marxista. Tradução de Rodnei Nascimento. São Paulo: Martins Fontes, 2003.

LÖWY, Michael. A jaula de aço. Max Weber e o marxismo weberiano. Tradução: Mariana Echalar. São Paulo: Boitempo, 2014.

MARX, Karl. O Capital: crítica da economia política. Tradução de Rubens Enderle. São Paulo: Boitempo, 2013.

Trabalho estranhado e propriedade privada. In: Manuscritos econômicofilosóficos. Tradução de Jesus Ranieri. São Paulo: Boitempo, 2004.

OUTHWAITE, Willian; BOTTOMORE, Tom. Dicionário do pensamento social do século XX. Editoria da edição brasileira: Renata Lessa, Wanderley Guilherme dos Santos. Rio de Janeiro: Jorge Zahar Editora, 1996.

TIEDEMANN, Rolf. Introdução da edição alemã. In: BENJAMIN, W. Passagens. Edição alemã de Rolf Tiedemann; Org. da edição brasileira: Wille Bolle. Belo Horizonte: Editora UFMG; São Paulo: Imprensa Oficial do Estado de São Paulo, 2009.

VASCONCELLOS, Caio Eduardo Teixeira. A teoria crítica e Max Weber. São Paulo. 254p. [Tese de doutorado] Universidade de São Paulo. Faculdade de Filosofia, Letras e Ciências Humanas, 2014.

WEBER, Max. A ética protestante e o espírito do capitalismo. Tradução de José Marques Mariane de Macedo. São Paulo: Companhia das Letras, 2004.

WEBER, Max. Metodologia das ciências sociais - parte 1. Tradução de Augustin Werner. São Paulo: Cortez Editora. Unicamp, 2001. 